\title{
DISCURSO DE POSSE DA PRESIDENTE DA ASSOCIAÇÃO BRASILEIRA DE ENFERMAGEM *
}

Excelentíssima Senhora D. Maria da Graça Simōes Côrte Imperial - Presidente desta Assembléia de Delegados

Excelentíssimas autoridades presentes ou representadas

Companheiras de Diretoria

Minhas Senhoras

Meus Senhores

Ilustres Colegas

Ao tomar posse na Presidência da Associaçāo Brasileira de Enfermagem, queremos dizer-lhes de nossas preocupaçōes diante do encargo que acabamos de assumir:

Por quase 50 anos, a única entidade representativa dos enfermeiros a nível nacional, a ABEn além de desempenhar suas funçōes eminentemente culturais, vinha procurando exercer um papel disciplinador do exercício profissional e agir em defesa da classe. $\mathrm{E}$, mesmo que lhe faltasse autoridade legal para tais empreendimentos, é grande para com ela a dívida das autoridades, a quem sempre forneceu valiosos subsídios, e nossa, porque sua luta foi sempre em favor de melhores condiçōes de trabalho, para a elevaçāo do padrāo da assistência de enfermagem.

No ano passado começaram a funcionar o Conselho Federal e os Regionais de Enfermagem, cuja açāo começaremos agora a sentir mais claramente, com a

* Ieda Barreira e Castro. entrada em vigor dos Códigos que regulam nosso exercício profissional. Por outro lado, em vários Estados estāo em processo de criação os Sindicatos de Enfermagem, órgãos de defesa de classe.

O aparecimento dessas entidades configura um período de transiçāo, em que a ABEn terá que atualizar-se; nāo propriamente buscando um outro papel, que este sempre foi e será o de definir a profissāo na sociedade brasileira; mas procurando novos caminhos e modos de desempenhar esse papel.

Esses delineamentos deverāo ser explicitados na política de trabalho do próximo quadriênio, que norteará as atividades da ABEn em todo o País.

A reforma do Estatuto, aprovada na Assembléia de Delegados na semana finda, já reflete essa nova condição: o ingresso dos estudantes de Enfermagem trará nova vitalidade à nossa Associação. Essas moças e rapazes doarāo os ideais de sua juventude ao mister de trabalhar pelo desenvolvimento da enfermagem brasileira. E, como sempre, serão agentes de mudança, contribuindo para a contínua adaptação dessa entidade ao panorama nacional. Entretanto, cabe a nós, associadas mais antigas, o dever de acompanhá-los, de modo a que não desanimem às primeiras dificuldades, de com eles compartilhar a nossa experiência, de ouvir seus anseios e de com eles crescer em sabedoria. 
O fortalecimento dos setores executivos incumbidos de promover e incentivar a pesquisa de enfermagem, a edição de literatura profissional e a documentação científica, amplia nossos horizontes. E embora represente também maiores encargos, o desenvolvimento dessas atividades virão de encontro a uma das necessidades mais prementes de nossa vida cultural.

A aproximação e a cooperação dos ćrgãos formadores de recursos humanos, daqueles prestadores de serviços, de saúde, objetivo do atual governo, representa um desafio para todas as instituiçōes da área da saúde. A integração docente-assistencial é um processo de interaçāo entre estudantes, profissionais (de ensino e de serviço) e a sociedade, e tem como objetivo efetuar o ensinoaprendizagem em situaçōes reais e produtivas, incorporando o trabalho à educação. Para que se alcance essa integração será necessário que haja o reconhecimento de uma responsabilidade conjunta (docente-serviço) pela melhoria do nível de saúde do País e um compromisso permanente de professores e alunos nos programas de trabalho dos serviços de saúde. A este desafio, não poderá a ABEn estar indiferente.

A inclusão, entre as finalidades da ABEn, da criação e manutenção de obra filantrópica, fez renascer o projeto de uma "casa de enfermeira", em favor da qual a ex-Seção Guanabara envidou esforços em passado próximo. Já havendo previsão financeira para este fim, de posse do terreno da Ilha do Governador, nesta cidade, e de projeto arquitetônico, cabe agora, lançarmo-nos à sua construção, tão logo os recursos sejam suficientes.

Todas as enfermeiras do Brasil estão lembradas da verdadeira cruzada que foi a construção da sede em Brasília. Nenhuma, ao visitá-la, arrepende-se do esforço despendido. Na verdade, aquele edifício representa hoje um patrimônio da ordem de quase dois milhões de cruzeiros, que é, ao mesmo tempo, símbolo de nossa capacidade e garantia de nosso poder.

Graças à Diretoria anterior, e principalmente aos esforços da Secretária Executiva da ABEn, Clarice Ferrarini e da Coordenadora da Comissão de Finanças Ir. Tereza Notarnicola, encontra-se esta casa perfeitamente instalada, faltando apenas aperfeiçoar a infraestrutura administrativa que suporte 0 seu pleno funcionamento.

Cabe ainda à Diretoria recém-empossada promover a reformulação do Regulamento Geral da ABEn, que normalize as disposiçōes estatutárias e de regimentos especiais que pautem suas atividades.

Entretanto, a implementação das tarefas anunciadas e a busca de novos caminhos dependem da ação integrada de todas as enfermeiras integrantes da ABEn, pois quanto maior diversidade nas opiniōes, maior será o número de respostas inovadoras aos problemas defrontados. $\mathbf{E}$ as inovaçōes é que impulsionam o progresso de uma profissão.

Os Congressos que acabam de se encerrar são prova da pujança a que atingiu a enfermagem brasileira nos seus cinquienta anos de existência. Isto nos lembra as graves responsabilidades de que estamos investidas a partir desse momento e faz sentirmo-nos humildes perante nossas doze antecessoras.

Mas de todos os modos, somos ainda gratas às colegas que nos honraram com a sua confiança, pois continuamos a pensar que, participar da Diretoria da ABEn é uma oportunidade rara de aperfeiçoamento profissional - e também pessoal - e que os benefícios daí advindos serão sempre maiores do que a dedicação exigida.

Eram essas as considerações que desejávamos fazer nesta oportunidade.

Muito obrigada. 